\title{
Evaluation of the Prognostic Importance of c-Myc and Bcl-2 Expressions and the Presence of Epstein-Barr Virus in Classical Hodgkin Lymphoma
}

\author{
Aydan KILIÇARSLAN ${ }^{1}$ D , Vedia ÖZTÜRK² iD, Aysun ŞENTÜRK YIKILMAZ³ iD, Mehmet DOĞAN ${ }^{4}$ iD, \\ Mesut AKYOL ${ }^{5}$ iD \\ Department of Pathology, 'Ankara Yıldırım Beyazıt University, School of Medicine, ANKARA, TURKEY, ${ }^{2}$ Van Education and Research Hospital, VAN, TURKEY \\ ${ }^{3}$ Department of Hematology, Ankara Atatürk Education and Research Hospital, ANKARA, TURKEY, ${ }^{4}$ Department of Pathology, Ankara Dr. Abdurrahman Yurtaslan \\ Oncology Education and Research Hospital, ANKARA, TURKEY, ${ }^{5}$ Department of Biostatistic, Ankara Yıldırım Beyazıt University, School of Medicine, ANKARA, TURKEY
}

\section{ABSTRACT}

Objective: Although classical Hodgkin lymphoma (cHL) has a relatively good prognosis, it also entails different treatment responses and involves patients who have different clinical courses. Our aim was to investigate c-Myc, Bcl-2 and EBV biomarkers in cHL and their relationship with the IPS score.

Material and Method: c-Myc and Bcl-2 immunohistochemical staining with EBER in situ hybridization (EBER-ISH) was applied to the paraffin sections of 94 cases diagnosed as cHL. These cases were classified into two groups as low and high clinical symptoms according to the International Prognostic Scores (IPS).

Results: Positive results were obtained in 83 (88.3\%) cases with c-Myc and 39 (43.5\%) cases with Bcl-2 while EBER-ISH was found positive in 42 $(44.7 \%)$ cases. No difference was found between the groups of low/high IP scores with respect to the positive or negative results of EBER-ISH, $\mathrm{Bcl}-2$ and c-Myc. When Bcl-2 and c-Myc positive cases were grouped together and compared to the IP scores of the remaining cHL cases, again no difference was seen. Extranodal involvement and bone marrow involvement was observed in 25 (26.5\%) and 9 (9.5\%) cases, respectively. Similarly, no statistically significant differences was found between these groups according to their positivity with EBER-ISH, Bcl-2 and c-Myc.

Conclusion: We could not find any relationship between Bcl-2, c-Myc and EBER-ISH positivity and the low/high IPS groups in cHL. New studies with larger series are needed in which more precise cut-off values are used and clinically and biologically heterogeneous groups of cHL patients are determined more clearly.

Key Words: Hodgkin lymphoma, c-Myc, Bcl-2, EBER

\section{INTRODUCTION}

Hodgkin lymphoma (HL) is a partially homogeneous neoplastic disorder due to its relatively indolent clinical course (1). However its histomorphological findings, immune phenotype, genotype, relationship with viruses and its responses to treatment may vary (2-7). Several clinical parameters (age, stage, subtype, tumor burden, etc.) are used as predictive factors in the HL patients lifespan and responses to treatment (8-10). Until now, genetic and molecular steps in the progression of $\mathrm{HL}$ have not been completely understood. Genetic and immunohistochemical studies have been conducted into multiple cell cycle regulators in the pathogenesis of HL. These studies include numerous biological markers such as apoptosis inhibitors (Bcl-2, bcl-X), tumor suppressors

(Turk Patoloji Derg 2018, 34:199-206)

Received : 12.03.2018 Accepted : 05.04.2018 (p-53, RB, etc.), proto-oncogenes (c-Myc, NOTCH1, IRF4, etc.), as well as the Epstein-Barr virus (11-18).

Certain biological markers are known to be predictive factors for success of treatment and recovery chance of some non-Hodgkin lymphoma (NHL) types. It has been shown that the presence of $\mathrm{Bcl}-2, \mathrm{c}-\mathrm{Myc}$, and $\mathrm{Bcl}-6$ expressions in diffuse large $\mathrm{B}$-cell lymphomas are related with poor prognosis $(19,20)$ and the presence of $p-53$ mutation in mantle cell lymphomas is a predictor of aggressive behaviour $(21,22)$. It has also been determined that presence of EBV in T-cell NHLs is related with poor prognosis $(23,24)$.

Several prognostic models are used to classify lymphoma patients into groups of high and low risk. The International Prognostic Score (IPS) consists of a combination of various

Correspondence: Aydan KILIÇARSLAN

Ankara Yıldırım Beyazıt University,

Department of Pathology, ANKARA, TURKEY

E-mail: dr.kilicaydan@gmail.com Phone: +90 5055619579 
clinical and laboratory parameters and the risk of a patient is determined by these parameters $(25,26)$. In fact, even in risk groups as determined by IPS, different treatment results may be obtained. Some researchers have tried to develop research models that use biological markers together with clinical prognostic models. Nevertheless, the independent prediction accuracy of these indicators is limited and not widely accepted.

In this study, we aimed to put forward $\mathrm{c}-\mathrm{Myc}, \mathrm{Bcl}-2$ and EBV status of cHL and whether these indicators are related with prognostic findings as determined by IPS.

\section{MATERIAL and METHODS}

Patients: Ninety-four cases diagnosed as classical Hodgkin Lymphoma (cHL) between 2007 and 2016 were included in the study. The cases were re-evaluated by two pathologists (A.K. and V.Ö.) according to the 2017 WHO classification criteria. Diagnostic blocks with cHL were chosen for immunohistochemical staining and EBER (Epstein-Barr virus-encoded RNA) in situ hybridization tests. Clinical parameters of prognostic importance were obtained through the computer files and data in the hematology and oncology clinics where these patients were monitored.

Clinicopathological data (age, sex, histological subtype, clinical stage, bone marrow involvement, prognostic score, the presence and date of relapse, together with the presence of extranodal involvement) of the cases were obtained from the patient files and were categorised by using IPS (International Prognostic Score). IPS scores were coded as 0,1 , and 2 representing "low" and 3 and above representing "high" risk.

\section{Immunohistochemistry}

3-4 $\mu \mathrm{m}$ thick sections were placed on slides covered with poly-L-lysine out of the blocks of cHL-diagnosed formalin-fixed paraffin-embedded biopsy samples for immunohistochemical studies. The standard protocol was applied by the Benchmark GX IHK/ISH (Ventana) automatic staining device for the anticors of c-Myc (clone Y69, Ventana) and Bcl-2 (clone 2/100/05, Novocastra). For both of the markers, stainings below $40 \%$ were regarded as "negative" and those above $40 \%$ were regarded as "positive" in Hodgkin/Reed-Sternberg (HRS) cells.

\section{EBER (EBV-encoded RNA) in Situ Hybridization}

EBER-ISH was applied to all cases using ISH iVIEW Blue Detection Kit (Ventana) with silver labeled oligonucleotide probes (INFORM EBER Probe, Ventana) in the Benchmark GX IHK/ISH (Ventana) autostainer device. After deparaffinization and soft and standard cell healing, 12 minutes of protease 3 , and the INFORM EBER steps were applied; then 6 minutes of red counterstain was performed on the background and dark-blue nuclear staining was considered to be positive in HRS cells.

\section{Statistical Analysis}

The SPSS for MacOS program was used to analyse the data. Discrete numeric variables of descriptive statistics were shown as mean \pm standard deviation or median (minimummaximum), nominal variables were shown as the number of cases and percentage (\%).

Nominal variables were evaluated by using Pearson's Kisquare or Fisher's exact test. The results for $\mathrm{p}<0.05$ were regarded as statistically significant.

\section{RESULTS}

Samples taken from a total of 94 patients of whom 33 were female $(35.1 \%)$ and 61 were male $(64.9 \%)$ and whose median age was 40.5 years (ranging between 15 and 75 years). Of the cases, 55 (58.5\%) were nodular sclerosing, 19 (20.2\%) were mixed cellular, 15 (16.0\%) were lymphocyte rich and 5 (5.3\%) of them were lymphocyte poor subtype.

Examined IPS scores were ranged between 0 and 7 , and the median IPS score was 2.0 (IQR=2.0). $63(67.0 \%)$ of the cHL cases were classified as low and 31 (32.9\%) as high risk categories.

While the staining rate for $\mathrm{c}-\mathrm{Myc}$ ranged between $0 \%$ and $100 \%$, the staining median for $\mathrm{c}-\mathrm{Myc}$ was calculated as $70.0 \%(\mathrm{IQR}=20.0)$ (Figure $1 \mathrm{~A}-\mathrm{B})$. The $\mathrm{Bcl}-2$ staining ranged between $10 \%$ and $100 \%$; and staining median was $0 \%(\mathrm{IQR}=60 \%)$ (Figure 2$)$.

Values below $40 \%$ were regarded as "negative" while $40 \%$ and above were regarded as positive for both of the markers. Accordingly, 83 (88.3\%) cases with c-Myc were seen to be positive while 39 (41.5\%) cases with Bcl-2 were evaluated as positive. EBV was determined as positive in 42 (44.7) cases (Figure 3).

No statistical significant difference was found, concerning EBV, Bcl-2 and c-Myc positivity between the low and high risk groups of IPS ( $p>0.05)$ (Table I).

Extranodal involvement was found in 25 (26.5\%) of the cases. No difference was found about Bcl-2 and c-Myc staining rates with relation to extranodal involvement (p>0.05) (Table II). However, 21 (84\%) of 25 cases with extranodal involvement also had positive staining with c-Myc. The rate of extranodal involvement in EBV positive cases was significantly higher than in EBV negative cases $(\chi 2=5.413 ; p=0.023)$. When all other factors (such as age, 
Table I: The staining rates with c-Myc, Bcl-2 and EBER-ISH in IP score groups

\begin{tabular}{|c|c|c|c|c|c|c|}
\hline \multicolumn{7}{|c|}{ IP Score Group } \\
\hline Marker & Result & Low & High & Total & $\chi^{2}$ & $\mathbf{p}$ \\
\hline \multirow{3}{*}{$\mathrm{c}-\mathrm{Myc}$} & Negative & $8(12.7)$ & $3(9,7)$ & $11(11.7)$ & \multirow{2}{*}{0,184} & \multirow{2}{*}{0.668} \\
\hline & Positive & $55(87.3)$ & $28(90,3)$ & $83(88.3)$ & & \\
\hline & Total & $63(100.0)$ & $31(100.0)$ & $94(100.0)$ & & \\
\hline \multirow{3}{*}{ Bcl-2 } & Negative & $38(60.3)$ & $17(54.8)$ & $55(58.5)$ & \multirow{2}{*}{0.257} & \multirow{2}{*}{0.612} \\
\hline & Positive & $25(39.7)$ & $14(45.2)$ & $39(41.5)$ & & \\
\hline & Total & $63(100.0)$ & $31(100.0)$ & $94(100.0)$ & \multirow{3}{*}{0.899} & \\
\hline \multirow{3}{*}{ EBER-ISH } & Negative & $37(58.7)$ & $15(48.4)$ & $52(55.3)$ & & \multirow{2}{*}{0.343} \\
\hline & Positive & $26(41.3)$ & $16(51.6)$ & $42(44.7)$ & & \\
\hline & Total & $63(100.0)$ & $31(100.0)$ & $94(100.0)$ & & \\
\hline
\end{tabular}
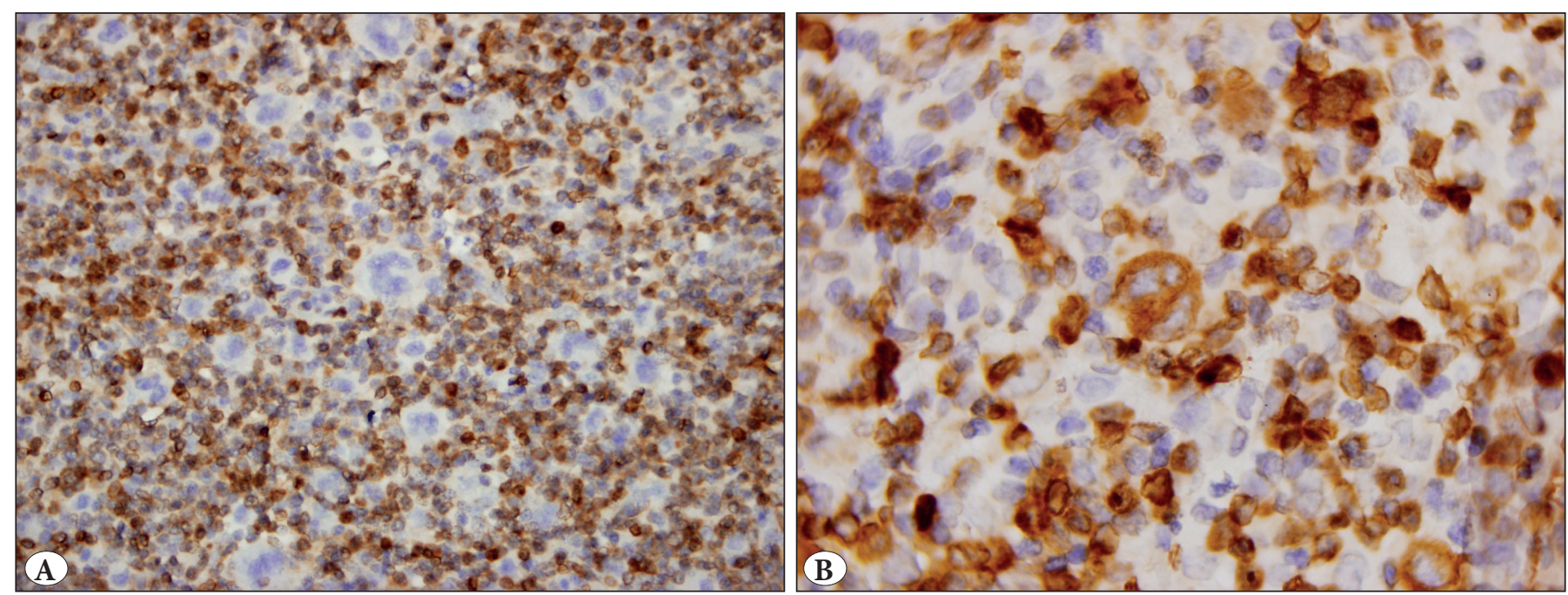

Figure 1: A) In Bcl-2 immunohistochemical staining, lymphocytes around HRS cells shows positive staining in the form of rosettes (IHC; $\mathrm{x} 40$ ). B) Cytoplasmic positive staining in HRS cells with Bcl-2 (IHC; x100).

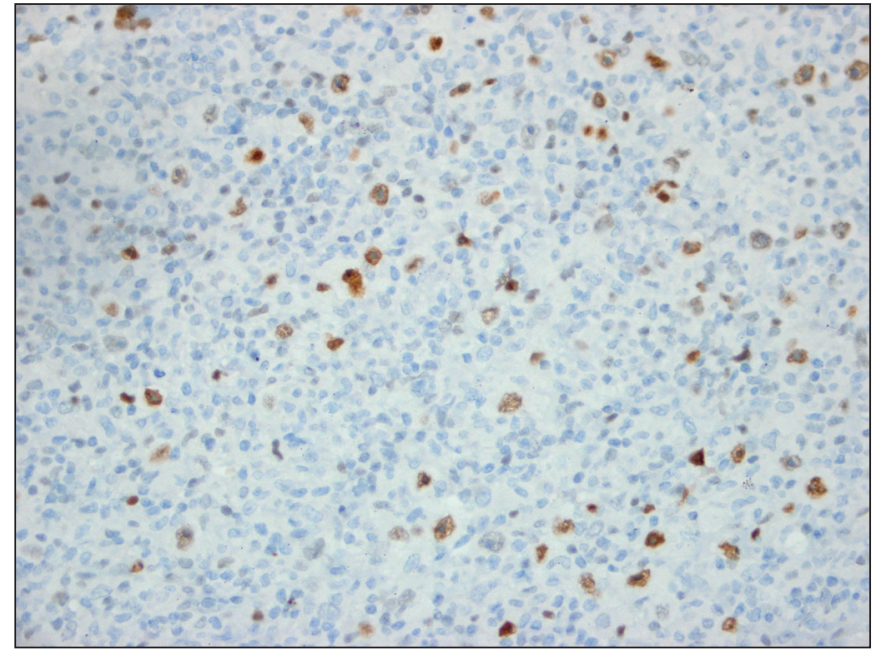

Figure 2: In c-Myc immunohistochemical staining, common positive staining is observed in HRS cells' nucleus (IHC; x400).

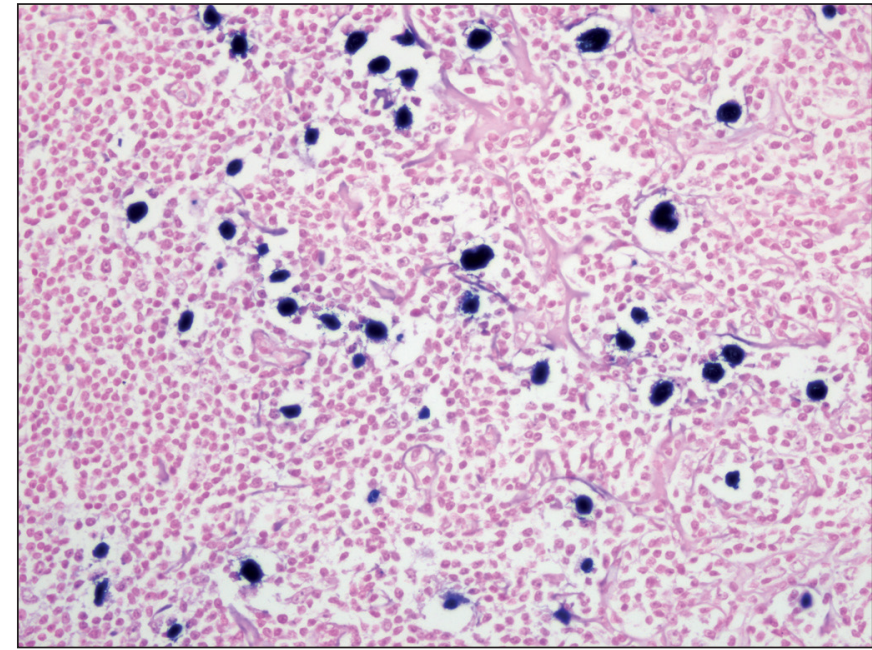

Figure 3: In EBER ISH, dark-blue nuclear staining was considered to be positive in HRS cells (CISH; $\mathrm{x} 400$ ). 
gender and the stage of illness) are assumed stable, the risk of extranodal involvement in EBV positive cases is $\mathrm{OR}=2.98$ ( 95\% CI: $1.16-7.65)$ times higher than in EBV negative cases.

Bone marrow involvement was seen in 9 (9.5\%) of the cases. No difference was found concerning the staining rates of c-Myc, Bcl-2 and EBER-ISH in relation to bone marrow involvement $(\mathrm{p}>0.05)$ (Table III). Positive stainig with c-Myc was found in 7 of the 9 cases with bone marrow involvement, and positive Bcl-2 was found in 3 of them.

EBV was found to be positive in 42 (44.6\%), and negative $52(55.3 \%)$ of the cases with EBER-ISH. No significant relationship was detected between EBER-ISH, c-Myc and Bcl-2 expressions (Table IV).

To observe any difference according the IP scores between $\mathrm{Bcl}-2+/ \mathrm{c}-\mathrm{Myc}+$ patients and the remaining patients, cases

Table II: The staining rates of c-Myc, Bcl-2 and EBER-ISH in relation to extranodal involvement

\begin{tabular}{|c|c|c|c|c|c|c|}
\hline \multicolumn{7}{|c|}{ Extranodal Involvement } \\
\hline Marker & Result & No & Yes & Total & $\chi^{2}$ & $\mathbf{P}$ \\
\hline \multirow{3}{*}{ c-Myc } & Negative & $7(10.1)$ & $4(16.0)$ & $11(11.7)$ & \multirow{2}{*}{ - } & \multirow{2}{*}{0.475} \\
\hline & Positive & $62(89.9)$ & $21(84.0)$ & $83(88.3)$ & & \\
\hline & Total & $69(100.0)$ & $25(100.0)$ & $94(100.0)$ & & \\
\hline \multirow{3}{*}{ Bcl-2 } & Negative & $42(60.9)$ & $13(52.0)$ & $55(58.5)$ & \multirow{2}{*}{0.595} & \multirow{2}{*}{0.441} \\
\hline & Positive & $27(39.1)$ & $12(48.0)$ & $39(41.5)$ & & \\
\hline & Total & $69(100.0)$ & $25(100.0)$ & $94(100.0)$ & \multirow{3}{*}{5.143} & \\
\hline \multirow{3}{*}{ EBER-ISH } & Negative & $43(62.3)$ & $9(36.0)$ & $52(55.3)$ & & \multirow{2}{*}{0.023} \\
\hline & Positive & $26(37.7)$ & $16(64.0)$ & $42(44.7)$ & & \\
\hline & Total & $69(100.0)$ & $25(100.0)$ & $94(100.0)$ & & \\
\hline
\end{tabular}

Table III: The staining rates of c-Myc, Bcl-2 and EBER-ISH in relation to bone marrow involvement

\begin{tabular}{|c|c|c|c|c|c|c|}
\hline \multicolumn{7}{|c|}{ Bone Marrow Involvement } \\
\hline Marker & Result & No & Yes & Total & $\chi^{2}$ & $\mathbf{p}$ \\
\hline \multirow{3}{*}{ c-Myc } & Negative & $9(10,6)$ & $2(22.2)$ & $11(11.7)$ & \multirow{2}{*}{-} & \multirow{2}{*}{0.283} \\
\hline & Positive & $76(89.4)$ & $7(77.8)$ & $83(88.3)$ & & \\
\hline & Total & $85(100.0)$ & $9(100.0)$ & $94(100.0)$ & & \\
\hline \multirow{3}{*}{ Bcl-2 } & Negative & $49(57.6)$ & $6(66.7)$ & $55(58.5)$ & \multirow{2}{*}{-} & \multirow{2}{*}{0.731} \\
\hline & Positive & $36(42.4)$ & $3(33.3)$ & $39(41.5)$ & & \\
\hline & Total & $85(100.0)$ & $9(100.0)$ & $94(10.0)$ & & \\
\hline \multirow{3}{*}{ EBER-ISH } & Negative & $49(57.6)$ & $3(33.3)$ & $52(55.3)$ & \multirow[b]{2}{*}{-} & \multirow{2}{*}{0.290} \\
\hline & Positive & $36(42.4)$ & $6(66.7)$ & $42(44.7)$ & & \\
\hline & Total & $85(100.0)$ & $9(100.0)$ & $94(100.0)$ & & \\
\hline
\end{tabular}

Table IV: The staining rates of $\mathrm{c}-\mathrm{Myc}$ and $\mathrm{Bcl}-2$ in relation to the EBER-ISH positivity

\begin{tabular}{lcccccc}
\hline Marker & Result & EBER-ISH Negative & EBER-ISH Positive & Total & $\boldsymbol{\chi}^{2}$ & $\mathbf{p}$ \\
\hline \multirow{3}{*}{ c-Myc } & Negative & $7(13.5)$ & $4(9.5)$ & $11(11.7)$ & & \multirow{2}{*}{0.749} \\
\cline { 2 - 5 } & Positive & $45(86.5)$ & $38(90.5)$ & $83(88.3)$ & & \\
\cline { 2 - 5 } Bcl-2 & Total & $\mathbf{5 2 ( 1 0 0 . 0 )}$ & $\mathbf{4 2 ( 1 0 0 . 0 )}$ & $\mathbf{9 4 ( 1 0 0 . 0 )}$ & & \\
\cline { 2 - 5 } & Negative & $27(51.9)$ & $28(66.7)$ & $55(58.5)$ & \multirow{2}{*}{2.080} & 0.149 \\
\cline { 2 - 5 } & Positive & $25(48.1)$ & $14(33.3)$ & $39(41.5)$ & & \\
\hline
\end{tabular}


Table V: The staining rates for IPS groups of $\mathrm{Bcl}-2+/ \mathrm{c}-\mathrm{Myc}+$ and the others

\begin{tabular}{lcccccc}
\hline \multicolumn{7}{c}{ IPS Score Group } \\
\hline Marker & Result & Low & High & Total & $\chi^{2}$ & p \\
\hline $\begin{array}{l}\text { Others } \\
\text { c-Myc }(+)+\end{array}$ & Negative & $40(63.5)$ & $18(58.1)$ & $\mathbf{5 8 ( 6 1 , 7 )}$ & 0.259 & 0.611 \\
\cline { 2 - 5 } Bcl-2(+) & Positive & $23(36.5)$ & $13(41.9)$ & $\mathbf{3 6 ( 3 8 . 3 )}$ & & \\
\cline { 2 - 5 } & Total & $\mathbf{6 3 ( 1 0 0 . 0 )}$ & $\mathbf{3 1 ( 1 0 0 . 0 )}$ & $\mathbf{9 4 1 0 0 . 0 )}$ & & \\
\hline
\end{tabular}

were reclassified into two groups: Bcl-2+/c-Myc+ cases and other cases (Bcl-2+/c-Myc-; Bcl-2-/c-Myc-; and Bcl-2-/c$\mathrm{Myc}+$ ) (Table V). There was no difference between the low and high IPS groups ( $>0.05)$.

\section{DISCUSSION}

A considerable number of HL cases are tumors that respond to first-line therapy (27). However,, in approximately $20 \%$ to $30 \%$, relapse, treatment complications and death from the disease occur $(28,29)$. Additionally, a sufficient response to standard treatment could not be obtained in more than one third of HL cases. The factors affecting treatment response in this patient group may include advanced stage disease, the presence of B symptoms, oncogenic proteins, or molecular abnormalities in the suppressor protein panels. In several studies, a comparison has been made between the biological markers that have potential routine use and the clinical results and the effects on known prognostic factors have been researched $(3,30,31)$.

Several proto-oncogenes may affect lymphoid malignancies and one of the most important of these is c-Myc (32). c-Myc plays role in various cellular functions such as cell cycle, cell growth, cell metabolism, biosynthesis, adhesion and also the control of mitochondrial function. The determination of $\mathrm{c}-\mathrm{Myc}$ protein expression and gene translocation is important in the diagnosis of lymphomas and specifying clinical sequence of aggressive B cell lymphomas $(33,34)$. It has been demonstrated that $\mathrm{c}-\mathrm{Myc}$ translocation is related with a poor prognosis in the subgroups of diffuse large $B$ cell lymphoma patients $(20,35)$. Additionally, it has also been shown that diffuse large B-cell lymphoma patients with co-expression of c-Myc, Bcl-6 and Bcl-2 proteins have a poor prognosis and do not respond to routine chemotherapy $(19,20,35)$. The presence of c-Myc has been searched in a limited number of studies concerning HL and positive staining was shown for the major part of those cases $(36,37)$. We aimed to show c-Myc expression status in cHL and to search whether there is any risk in terms of IPS risk groups. However, we were unable to obtain any significant difference between the low and high risk IPS groups. Besides, in 61 (68.5\%) of 89 cases, IPS was found to be low. Moreover, there was no bone marrow involvement in $82(92.1 \%)$ and no extranodal involvement in 68 (76.4\%) out of these 89 cases.

Biological markers such as Bcl-2, BAX, Bcl-X and p53 are proteins that organize apoptosis. High staining rates of Bcl-2 in HRS cells have been associated with negative consequences in HL patients in some studies $(5,12,38)$. In our study, we did not find any significant relationship between Bcl-2 expression in HRS and the low and high risk IPS groups. Furthermore, $25(64,1 \%)$ out of $39 \mathrm{Bcl}-2$ positive cases were grouped as low risk IPS. Also, out of 39 cases that were stained Bcl-2 positive, 27 (69.2\%) and $36(92.3 \%)$ cases had no extranodal involvement and no bone marrow involvement, respectively. The chosen method and the cut-off value regarding positivity may have resulted differently in previous studies. There aren't many articles concerning the staining threshold of $\mathrm{c}-\mathrm{Myc}$ and Bcl-2 expressions in HL. In certain studies mentioning significant differences, $10 \%$ has been used as a threshold for Bcl-2 positivity, regarding the clinical consequences of HL $(3,5,38)$. In studies that assumed the threshold as $20 \%$ and above, no relationship has been found in the same context $(12,39)$. However, diffuse large B-cell lymphoma studies concerning c-Myc and $\mathrm{Bcl}-2$ expression, usually $40 \%$ and above positivity is used as cut-off point $(40,41)$. Hence, we preferred to use the same scope for our study, but this may be the cause that why we could not find any significant relationship between Bcl-2/c-Myc expressions and IP scores. This leads to stating the limitation of our study, not including either applied therapy or the results of the treatment for the patients .

In the literature, the Epstein-Barr virus (EBV) has been determined to be positive in $47.9 \%$ of cHL patients (42). Whether there is a relationship between EBV infection and the advanced clinical stages of cHL is highly debatable. While some studies (43-45) have found an important correlation between EBV and the advanced stage of cHL, other studies have not found such a relationship (46-48). We found that 42 (44.7\%) of cHL cases were EBV positive. We could not find any difference between positive and negative EBV cases in terms of IPS and bone marrow involvement, but, there was significantly high extranodal 
involvement in those cases which were EBV positive. Besides, no relationship was found between EBER-ISH and $\mathrm{Bcl}-2 / \mathrm{c}-\mathrm{Myc}$ expressions in our series. These markers have been defined as independent factors from each other in other literature $(6,15,49)$.

Finally, we also researched whether co-expression of c-Myc and Bcl-2 is related with low and high risk IP scores, but we could not find any significant result.

It is concluded that future studies with larger series may lead to finding an optimal cut-off value for $\mathrm{c}-\mathrm{Myc}$ and Bcl2 and can provide more prognostic information in cHL, including determining treatment-resistant/high-risk cases.

\section{CONFLICT of INTEREST}

The authors declare no conflict of interest.

\section{REFERENCES}

1. Canellos GP. Treatment of relapsed Hodgkin's disease: Strategies and prognostic factors. Ann Oncol. 1998; 9:S91-6.

2. Sieber M, Engert A, Diehl V. Treatment of Hodgkin's disease: Results and current concepts of the German Hodgkin's Lymphoma Study Group. Ann Oncol. 2000; 11:81-5.

3. Smolewski P, Robak T, Krykowski E, Blasinska-Morawiec M, Niewiadomska H, Pluzanska A, Chmielowska E, Zambrano O. Prognostic factors in Hodgkin's disease: Multivariate analysis of 327 patients from a single institution. Clin Cancer Res. 2000;6:1150-60.

4. Hinz M, Loser P, Mathas S, Krappmann D, Dorken B, Scheidereit C. Constitutive NF-kappaB maintains high expression of a characteristic gene network, including CD40, CD86, and a set of antiapoptotic genes in Hodgkin/Reed-Sternberg cells. Blood. 2001;97:2798-807.

5. Sup SJ, Alemany CA, Pohlman B, Elson P, Malhi S, Thakkar S, Steinle R, Hsi ED. Expression of bcl-2 in classical Hodgkin's lymphoma: An independent predictor of poor outcome. J Clin Oncol. 2005;23:3773-9.

6. Kim LH, Nadarajah VS, Peh SC, Poppema S. Expression of Bcl-2 family members and presence of Epstein-Barr virus in the regulation of cell growth and death in classical Hodgkin's lymphoma. Histopathology. 2004;44:257-67.

7. Morente MM, Piris MA, Abraira V, Acevedo A, Aguilera B, Bellas C, Fraga M, Garcia-Del-Moral R, Gomez-Marcos F, Menarguez J, Oliva H, Sanchez-Beato M, Montalban C. Adverse clinical outcome in Hodgkin's disease is associated with loss of retinoblastoma protein expression, high Ki67 proliferation index, and absence of Epstein-Barr virus-latent membrane protein 1 expression. Blood. 1997;90:2429-36.

8. Zander T, Wiedenmann S, Wolf J. Prognostic factors in Hodgkin's lymphoma. Ann Oncol. 2002;13:67-74.

9. Ferme C, Bastion Y, Brice P, Lederlin P, Divine M, Gabarre J, Assouline D, Ferrant A, Berger F, Lepage E. Prognosis of patients with advanced Hodgkin's disease: Evaluation of four prognostic models using 344 patients included in the Group d'Etudes des Lymphomes de l'Adulte Study. Cancer. 1997;80:1124-33.
10. Vassilakopoulos TP, Angelopoulou MK, Siakantaris MP, Kontopidou FN, Dimopoulou MN, Barbounis A, Grigorakis V, Karkantaris C, Anargyrou K, Chatziioannou M, Rombos J, Boussiotis VA, Vaiopoulos G, Kittas C, Pangalis GA. Prognostic factors in advanced stage Hodgkin's lymphoma: The significance of the number of involved anatomic sites. Eur J Haematol. 2001;67:279-88.

11. Brink AA, Oudejans JJ, van den Brule AJ, Kluin PM, Horstman A, Ossenkoppele GJ, van Heerde P, Jiwa M, Meijer CJ. Low p53 and high bcl-2 expression in Reed-Sternberg cells predicts poor clinical outcome for Hodgkin's disease: Involvement of apoptosis resistance? Mod Pathol. 1998;11:376-83.

12. Montalban C, Garcia JF, Abraira V, Gonzalez-Camacho L, Morente MM, Bello JL, Conde E, Cruz MA, Garcia-Sanz R, Garcia-Larana J, Grande C, Llanos M, Martinez R, Flores E, Mendez M, Ponderos C, Rayon C, Sanchez-Godoy P, Zamora $\mathrm{J}$, Piris MA. Influence of biologic markers on the outcome of Hodgkin's lymphoma: A study by the Spanish Hodgkin's Lymphoma Study Group. J Clin Oncol. 2004;22:1664-73.

13. Keegan TH, Glaser SL, Clarke CA, Gulley ML, Craig FE, Digiuseppe JA, Dorfman RF, Mann RB, Ambinder RF. EpsteinBarr virus as a marker of survival after Hodgkin's lymphoma: A population-based study. J Clin Oncol. 2005;23:7604-13.

14. Montesinos-Rongen M, Roers A, Kuppers R, Rajewsky K, Hansmann ML. Mutation of the p53 gene is not a typical feature of Hodgkin and Reed-Sternberg cells in Hodgkin's disease. Blood. 1999;94:1755-60.

15. Jiwa NM, Kanavaros P, van der Valk P, Walboomers JM, Horstman A, Vos W, Mullink H, Meijer CJ. Expression of c-myc and bcl-2 oncogene products in Reed-Sternberg cells independent of presence of Epstein-Barr virus. J Clin Pathol. 1993;46:211-7.

16. Kim LH, Peh SC, Poppema S. Expression of retinoblastoma protein and P16 proteins in classic Hodgkin lymphoma: Relationship with expression of p53 and presence of Epstein-Barr virus in the regulation of cell growth and death. Hum Pathol. 2006;37:92-100.

17. Ohshima K, Haraoka S, Fujiki T, Yoshioka S, Suzumiya J, Kanda M, Kikuchi M. Expressions of cyclin E, A, and B1 in Hodgkin and Reed-Sternberg cells: Not suppressed by cyclin-dependent kinase inhibitor p21 expression. Pathol Int. 1999;49:506-12.

18. Tiacci E, Doring C, Brune V, van Noesel CJ, Klapper W, Mechtersheimer G, Falini B, Kuppers R, Hansmann ML. Analyzing primary Hodgkin and Reed-Sternberg cells to capture the molecular and cellular pathogenesis of classical Hodgkin lymphoma. Blood. 2012;120:4609-20.

19. Akyurek N, Uner A, Benekli M, Barista I. Prognostic significance of MYC, BCL2, and BCL6 rearrangements in patients with diffuse large B-cell lymphoma treated with cyclophosphamide, doxorubicin, vincristine, and prednisone plus rituximab. Cancer. 2012;118:4173-83.

20. Bellas C, Garcia D, Vicente Y, Kilany L, Abraira V, Navarro B, Provencio M, Martin P. Immunohistochemical and molecular characteristics with prognostic significance in diffuse large B-cell lymphoma. PLoS One. 2014;9:e98169. 
21. Zlamalikova L, Moulis M, Ravcukova B, Liskova K, Malcikova J, Salek D, Jarkovsky J, Svitakova M, Hrabalkova R, Smarda J, Smardova J. Complex analysis of the TP53 tumor suppressor in mantle cell and diffuse large B-cell lymphomas. Oncol Rep. 2017;38:2535-42.

22. Stefancikova L, Moulis M, Fabian P, Ravcukova B, Vasova I, Muzik J, Malcikova J, Falkova I, Slovackova J, Smardova J. Loss of the p53 tumor suppressor activity is associated with negative prognosis of mantle cell lymphoma. Int J Oncol. 2010;36:699706.

23. Leong IT, Fernandes BJ, Mock D. Epstein-Barr virus detection in non-Hodgkin's lymphoma of the oral cavity: An immunocytochemical and in situ hybridization study. Oral Surg Oral Med Oral Pathol Oral Radiol Endod. 2001;92:184-93.

24. Takada H, Imadome KI, Shibayama H, Yoshimori M, Wang L, Saitoh Y, Uota S, Yamaoka S, Koyama T, Shimizu N, Yamamoto K, Fujiwara S, Miura O, Arai A. EBV induces persistent NFkappaB activation and contributes to survival of EBV-positive neoplastic T- or NK-cells. PLoS One. 2017;12:e0174136.

25. Franklin J, Paulus U, Lieberz D, Breuer K, Tesch H, Diehl V. Is the international prognostic score for advanced stage Hodgkin's disease applicable to early stage patients? German Hodgkin Lymphoma Study Group. Ann Oncol. 2000;11:617-23.

26. Fu XH, Wang SS, Huang Y, Wang B, Huang HQ, Zhang L, Sun $\mathrm{XF}, \mathrm{Xu} \mathrm{RH}$, Lin T. Feasibility study of application of international prognostic score on prediction of prognosis for advanced Hodgkin's lymphoma. Ai Zheng. 2006;25:1013-8.

27. Canellos GP, Rosenberg SA, Friedberg JW, Lister TA, Devita VT. Treatment of Hodgkin lymphoma: A 50-year perspective. J Clin Oncol. 2014;32:163-8.

28. Sureda A, Arranz R, Iriondo A, Carreras E, Lahuerta JJ, GarciaConde J, Jarque I, Caballero MD, Ferra C, Lopez A, GarciaLarana J, Cabrera R, Carrera D, Ruiz-Romero MD, Leon A, Rifon J, Diaz-Mediavilla J, Mataix R, Morey M, Moraleda JM, Altes A, Lopez-Guillermo A, de la Serna J, Fernandez-Ranada JM, Sierra J, Conde E. Autologous stem-cell transplantation for Hodgkin's disease: Results and prognostic factors in 494 patients from the Grupo Espanol de Linfomas/Transplante Autologo de Medula Osea Spanish Cooperative Group. J Clin Oncol. 2001;19:1395404.

29. Karantanos T, Politikos I, Boussiotis VA. Advances in the pathophysiology and treatment of relapsed/refractory Hodgkin's lymphoma with an emphasis on targeted therapies and transplantation strategies. Blood Lymphat Cancer. 2017;7:37-52.

30. Gruss HJ, Kadin ME. Pathophysiology of Hodgkin's disease: Functional and molecular aspects. Baillieres Clin Haematol. 1996;9:417-46.

31. Spieker T, Kurth J, Kuppers R, Rajewsky K, Brauninger A, Hansmann ML. Molecular single-cell analysis of the clonal relationship of small Epstein-Barr virus-infected cells and Epstein-Barr virus-harboring Hodgkin and Reed/Sternberg cells in Hodgkin disease. Blood. 2000;96:3133-8.

32. Dang CV, O’Donnell KA, Zeller KI, Nguyen T, Osthus RC, Li F. The c-Myc target gene network. Semin Cancer Biol. 2006;16:25364 .
33. Swerdlow SH, Campo E, Pileri SA, Harris NL, Stein H, Siebert R, Advani R, Ghielmini M, Salles GA. The 2016 revision of the World Health Organization classification of lymphoid neoplasms. Blood. 2016;127:2375-90.

34. Le Gouill S, Talmant P, Touzeau C, Moreau A, Garand R, JugeMorineau N, Gaillard F, Gastinne T, Milpied N, Moreau P, Harousseau JL, Avet-Loiseau H. The clinical presentation and prognosis of diffuse large B-cell lymphoma with $t(14 ; 18)$ and 8q24/c-MYC rearrangement. Haematologica. 2007;92:1335-42.

35. Yan LX, Liu YH, Luo DL, Zhang F, Cheng Y, Luo XL, Xu J, Cheng J, Zhuang HG. MYC expression in concert with BCL2 and BCL6 expression predicts outcome in Chinese patients with diffuse large B-cell lymphoma, not otherwise specified. PLoS One. 2014;9:e104068.

36. Yuan Y, Kluiver J, Koerts J, de Jong D, Rutgers B, Abdul Razak FR, Terpstra M, Plaat BE, Nolte IM, Diepstra A, Visser L, Kok $\mathrm{K}$, van den Berg A. miR-24-3p is overexpressed in Hodgkin Lymphoma and protects Hodgkin and Reed-Sternberg Cells from Apoptosis. Am J Pathol. 2017;187:1343-55.

37. Polack A, Hortnagel K, Pajic A, Christoph B, Baier B, Falk M, Mautner J, Geltinger C, Bornkamm GW, Kempkes B. c-myc activation renders proliferation of Epstein-Barr virus (EBV)-transformed cells independent of EBV nuclear antigen 2 and latent membrane protein 1. Proc Natl Acad Sci USA. 1996;93:10411-6.

38. Rassidakis GZ, Medeiros LJ, Vassilakopoulos TP, Viviani S, Bonfante V, Nadali G, Herling M, Angelopoulou MK, Giardini R, Chilosi M, Kittas C, McDonnell TJ, Bonadonna G, Gianni AM, Pizzolo G, Pangalis GA, Cabanillas F, Sarris AH. BCL2 expression in Hodgkin and Reed-Sternberg cells of classical Hodgkin disease predicts a poorer prognosis in patients treated with ABVD or equivalent regimens. Blood. 2002;100:3935-41.

39. Garcia JF, Camacho FI, Morente M, Fraga M, Montalban C, Alvaro T, Bellas C, Castano A, Diez A, Flores T, Martin C, Martinez MA, Mazorra F, Menarguez J, Mestre MJ, Mollejo M, Saez AI, Sanchez L, Piris MA. Hodgkin and Reed-Sternberg cells harbor alterations in the major tumor suppressor pathways and cell-cycle checkpoints: Analyses using tissue microarrays. Blood. 2003; 101:681-9.

40. Meyer N, Penn LZ. Refl ecting on 25 years with MYC. Nat Rev Cancer. 2008;8:976-90.

41. Tapia G, Lopez R, Munoz-Marmol AM, Mate JL, Sanz C, Marginet R, Navarro JT, Ribera JM, Ariza A. Immunohistochemical detection of MYC protein correlates with MYC gene status in aggressive B cell lymphomas. Histopathology. 2011;59:672-8.

42. Lee JH, Kim Y, Choi JW, Kim YS. Prevalence and prognostic significance of Epstein-Barr virus infection in classical Hodgkin's lymphoma: A meta-analysis. Arch Med Res. 2014; 45:417-31.

43. Al-Kuraya K, Narayanappa R, Al-Dayel F, El-Solh H, Ezzat A, Ismail H, Belgaumi A, Bavi P, Atizado V, Sauter G, Simon R. Epstein-Barr virus infection is not the sole cause of high prevalence for Hodgkin's lymphoma in Saudi Arabia. Leuk Lymphoma. 2006; 47:707-13.

44. Spacek M, Hubacek P, Markova J, Zajac M, Vernerova Z, Kamaradova K, Stuchly J, Kozak T. Plasma EBV-DNA monitoring in Epstein-Barr virus-positive Hodgkin lymphoma patients. Apmis. 2011;119:10-6. 
45. Kwon JM, Park YH, Kang JH, Kim K, Ko YH, Ryoo BY, Lee SS, Lee SI, Koo HH, Kim WS. The effect of Epstein-Barr virus status on clinical outcome in Hodgkin's lymphoma. Ann Hematol. 2006;85:463-8.

46. Souza EM, Baiocchi OC, Zanichelli MA, Alves AC, Assis MG, Eiras DP, Dobo C, Oliveira JS. Impact of Epstein-Barr virus in the clinical evolution of patients with classical Hodgkin's lymphoma in Brazil. Hematol Oncol. 2010;28:137-41.

47. Chabay PA, Barros MH, Hassan R, De Matteo E, Rey G, Carrico MK, Renault IZ, Preciado MV. Pediatric Hodgkin lymphoma in 2 South American series: A distinctive epidemiologic pattern and lack of association of Epstein-Barr virus with clinical outcome. J Pediatr Hematol Oncol. 2008;30:285-91.
48. Trimeche M, Bonnet C, Korbi S, Boniver J, de Leval L. Association between Epstein-Barr virus and Hodgkin's lymphoma in Belgium: A pathological and virological study. Leuk Lymphoma. 2007;48:1323-31.

49. Khan G, Gupta RK, Coates PJ, Slavin G. Epstein-Barr virus infection and bcl-2 proto-oncogene expression. Separate events in the pathogenesis of Hodgkin's disease? Am J Pathol. 1993;143:1270-4. 